\title{
Nursing intervention assessment tool fall prevention in elderly people with systemic arterial hypertension
}

\author{
Paula Cristina Morais Pinheiro ${ }^{1}$, Glauciano de Oliveira Ferreira ${ }^{1}$, Francisca Valúzia Guedes Guerra ${ }^{1}$, Tahissa Frota \\ Cavalcante $^{1}$, Nirla Gomes Guedes ${ }^{2}$, Rafaella Pessoa Moreira*1 \\ ${ }^{1}$ Institute of Sciences of the Health. Universidade da Integração Internacional da Lusofonia Afro-Brasileira. Redenção, Ceará, \\ Brazil \\ ${ }^{2}$ School of Pharmacology, Dentistry and Nursing. Universidade Federal do Ceará. Fortaleza, Ceará, Brazil
}

Received: October 8, 2019

DOI: $10.5430 /$ jnep.v10n7p60
Accepted: April 6, 2020

URL: https://doi.org/10.5430/jnep.v10n7p60

\begin{abstract}
Background and objective: Elderly people are at greater risk for falls and, therefore, need effective interventions to prevent them. The aim of the study was to develop an assessment tool for nursing intervention fall prevention to elderly with arterial hypertension and with nursing diagnosis Risk of falls.

Methods: A methodological study, accomplished in four stages: activities selection of the fall Prevention intervention from Nursing Interventions Classification (NIC); 2) construction of constructive definitions and operational for selected activities; 3) expert validation of constructed definitions; 4) pretest of the final assessment tool.

Results: The experts selected 50 activities out of 65 presented by NIC. The constitutive and operational definitions of the 50 activities were elaborated. From the focus group, some activities were grouped and the content of others changed. The pretest showed that, although the application of the assessment tool with the definitions take longer, it was more complete and targeted. The final assessment tool contains 28 activities with constitutive definitions and operational.

Conclusions: The produced assessment tool has nursing activities with constitutive and operational definitions suitable for clinical nursing practice. It is believed that it can lead the intervention of the nurses in preventing falls in elderly people with SAH and with the nursing diagnosis Risk of falls.
\end{abstract}

Key Words: Elderly people, Fall accidents, Hypertension, Nursing

\section{INTRODUCTION}

Population aging is a worldwide phenomenon. With this, the number of falls that impacts on morbidity and mortality increases, with an increase in the demand for health services and nursing care needs. ${ }^{[1]}$

Falling is an unintentional displacement of the body to a level below the starting position. ${ }^{[2]}$ For (NANDA-I), it constitutes a nursing diagnosis, defined as: "Increased susceptibility to falls that can cause physical harm and compromise health" [3]

In addition to disability, institutionalization and death in elderly people, falls favor a reduction in quality of life, especially, in people with non-communicable chronic diseases, ${ }^{[4]}$ such as systemic arterial hypertension. ${ }^{[5,6]}$

Studies show the association between arterial hypertension and susceptibility to falls. ${ }^{[5-8]}$ One of them pointed out that this type of vascular disease can interfere in the maintenance

\footnotetext{
*Correspondence: Rafaella Pessoa Moreira; Email: rafaellapessoa@unilab.edu.br; Address: Institute of Sciences of the Health. Universidade da Integração Internacional da Lusofonia Afro-Brasileira, Redenção, Ceará, Brazil.
} 
of the static posture of elderly people, increasing their risk of falling. ${ }^{[7]}$ In Australia, a survey found that a higher dose of antihypertensive medication increased the risk of falls in elderly people. ${ }^{[5]}$

In view of this, it is indispensable to identify elderly people at risk of falls and to implement effective interventions to prevent them. For this, one of the assessment tools used worldwide is the Nursing Interventions Classification (NIC). It proposes, among its interventions, Fall Prevention, defining it as the "institution of special precautions for patients at risk of injury due to falls". [9]

The intervention Fall Prevention includes sixty-five activities, directed to different audiences and contexts such as children, elderly people, and hospitalized patients. ${ }^{[9]}$ Therefore, it is necessary to adapt it to groups and specific clinical conditions, such as elderly people with systemic arterial hypertension.

Despite this evident need, the studies are still incipient for the adequation of nursing interventions, especially, Fall Prevention. In this sense, the development of an assessment tool to prevent the occurrence of this event in elderly people with arterial hypertension is in consonance with the World Health Organization (WHO), which established chronic diseases as the second health priority for 2019. ${ }^{[10]}$ One of the priorities it is to prevent injuries and complications in people with arterial hypertension and diabetes mellitus.

Given the evident and relevant need to intervene to prevent falls in hypertensive elderly people, this study aimed to develop an assessment tool for nursing intervention fall Prevention in elderly with arterial hypertension and the nursing diagnosis Risk of falls.

\section{METHOD}

It was a methodological study, conducted in four stages, between July and December 2018, in the city of Redenção, Ceará, Brazil. The steps were: selection of the intervention activities Fall Prevention of NIC (2016), ${ }^{[9]}$ construction of constitutive definitions and operational for selected activities, expert validation of constructed definitions, and pretesting of the final assessment tool.

The first stage was performed with 22 specialist nurses who selected the activities of Intervention Fall Prevention of NIC (2016), ${ }^{[9]}$ more appropriate to elderly people with systemic arterial hypertension. To select the experts, it was used the criteria adapted from the scoring system proposed by Fehring. This author recommends that for a nurse to be considered a specialist he must have at least a Master degree in Nursing with a defined area of clinical experience. In addition to the

Published by Sciedu Press academic degree of master, the specialist needs to demonstrate specific knowledge about the phenomenon under study by means of presented and published research, scientific articles, clinical practice and specialization in the study area. ${ }^{[11]}$

The adapted criteria were: a nurse with at least a master's degree in courses included in the major health area of CAPES (Coordination for higher Education Staff Development) and obtaining a minimum score of five points in the adapted criteria of Fehring scoring system. ${ }^{[11]}$

All of them received, via e-mail, an online form built through Google forms. In this form, sociodemographic data were collected and made the selection of activities of the intervention Fall Prevention. The experts had two options for judging the activities: "applicable" or "not applicable". For the next stage, were included those that obtained at least $50 \%$ of approval.

In the second stage, performed between July and September 2018, were created the constitutive definitions and operational of the activities selected in the previous stage. For this, it was performed a narrative review of the literature, with searches on Google academic and in databases as LILACS, MEDLINE and, when necessary, books, dictionaries and technical manuals.

The inclusion criteria of the documents were: electronically available, published in the last five years, approaching the themes fall and arterial hypertension. When a constitutive and operational definition for any of the activities was not identified in the literature, the researchers elaborated, according to their experience.

Concerning the third stage, performed between October and November 2018, participated 06 specialist nurses contacted through an invitation letter sent by e-mail. To select the experts, the Fehring (1994) criteria were used with the adaptations deemed necessary, as already described. ${ }^{[11]}$ A meeting was held with the experts, called the focus group, in which the experts evaluated both the activities as their constitutive definitions and operational.

The focus group took place in three meetings. Each activity with its constitutive definitions and operational was projected in larger size by means of an overhead projector and orally presented by the mediator of the group. It was made the narrative record of all considerations given by experts in each meeting. It was considered consensus among them for final version of the assessment tool.

The fourth stage took place in December 2018 and consisted in the realization of a pretest of the assessment tool. For this, were selected four nurses from Primary Health Care and 
four elderly people with arterial hypertension and nursing diagnosis Risk of falls. To identify this diagnosis, it was used an assessment tool with 3 risk factors of NANDA-I (2018), ${ }^{[3]}$ marking them as "absent" or "present". The researcher, based on her clinical knowledge, made the diagnostic inference.

The participation criteria for nurses were: acting in primary health care in the city of Redenção; have at least 1 year of experience in assisting elderly people with arterial hypertension; be familiar with nursing classifications NANDA-I and NIC.

As for elderly people, the criteria of selection were: age 60 years or older; active registration in the public health center; have physical conditions for displacement, be present at the public health center on the appointed day for data collection and present nursing diagnosis Risk of falls. Were chosen the first four nurses and elderly people who expressed interest in voluntarily participate of the study and who fit the inclusion criteria.

For the pretest, a pair of nurses (01 and 02) applied the assessment tool with the activities and its constitutive definitions and operational, while another pair (nurse 03 and 04) applied the assessment tool with the same activities, but without definitions. Each of them performed the application with different elderly people and at different times. To evaluate this step, it was used active observation, guided by a guiding assessment tool and an audio recorder.

Ethical aspects were respected at all stages of this study. The research was approved by the Research Ethics Committee of the Universidade da Integração Internacional da Lusofonia Afro-Brasileira (UNILAB - University of International Integration of Afro-Brazilian Lusophony) with the opinion number 2.786.561.

\section{Results}

In the first stage of the study, only 17 specialists answered the form, 12 nursing teachers and 05 nurses of clinical practice. Of this total, $82.4 \%$ were female, with an average age of 34.64 years. As for the time of formation, the average was 07 years, with teaching experience equivalent to 06 years. Between 60 NIC activities, 50 were considered adequate to elderly people with arterial hypertension and with nursing diagnosis Risk of falls.

In the second stage, it was performed the construction of constitutive definitions and operational of the activities selected in the first stage. As for the third stage, the focus group experts pointed out that the extension of the assessment tool could make its use in clinical practice infeasible.

Thus, it was consensus among them that the assessment tool should be more concise. They suggested, therefore, the unification of activities with similar content, the exclusion of those inappropriate for elderly people target of the study and the alteration in the wording of some activities, to make them more understandable to the nurse, elderly people, their families and caregivers.

In addition to the mentioned changes, experts suggested to modify the order of presentation of the activities indicated by the NIC (2016). It was proposed that activities with similar content stay close. Thus, at the end of the first focus group meeting, only 28 of the 50 activities selected in the first stage were considered appropriate to prevention of falls in elderly people with arterial hypertension.

Experts agreed that it was attribution of the nurse to provide guidance, directed not only to elderly people, but also to their caregivers and family members. It was justified that this could promote the patient's self-care ability and would work on the empowerment of family members and caregivers. In view of this, it was suggested to write the activities in the following way: "guide the elderly people, their caregivers and family members", removing the following terms: "provide" and "do".

Moreover, it was recommended to substitute the term "patient" for "elderly people", indicated to all activities. In Table 1 there is a reduced version of the final assessment tool with 28 activities and their operational definitions. The larger version is available in Pinheiro's study (2018). ${ }^{[12]}$

Regarding the fourth stage of the study, the assessment tool application with the operational definitions by nurse 01 took approximately 56 minutes. He strictly followed the questions and the operational definitions suggested in the assessment tool. The nurse reported that he had no difficulty in applying the assessment tool and that the assessment tool was complete, containing all the operating instructions to perform each activity.

About the nurse 02, this took about 01 hour and 21 minutes. It was realized that he found difficulty in verbalizing the commands for physical and cognitive tests, manifesting difficulty in expressing himself clearly. Nevertheless, elderly people followed the guidelines related to suggested tests in the operational definition, such as the Tinetti test.

Concerning the adequation to public, the nurse 02 reported the assessment tool needs adjustments, because its items are not suitable for illiterate elderly people, which can cause embarrassment in those who cannot perform the suggested actions. Another review of professional was about the assessment tool extension. For him, this would make more difficult its implementation in clinical practice. 
Table 1. Reduced version of the assessment tool for Nursing Intervention Fall prevention in elderly people with systemic arterial hypertension, Redenção, Ceará, Brazil, 2018.

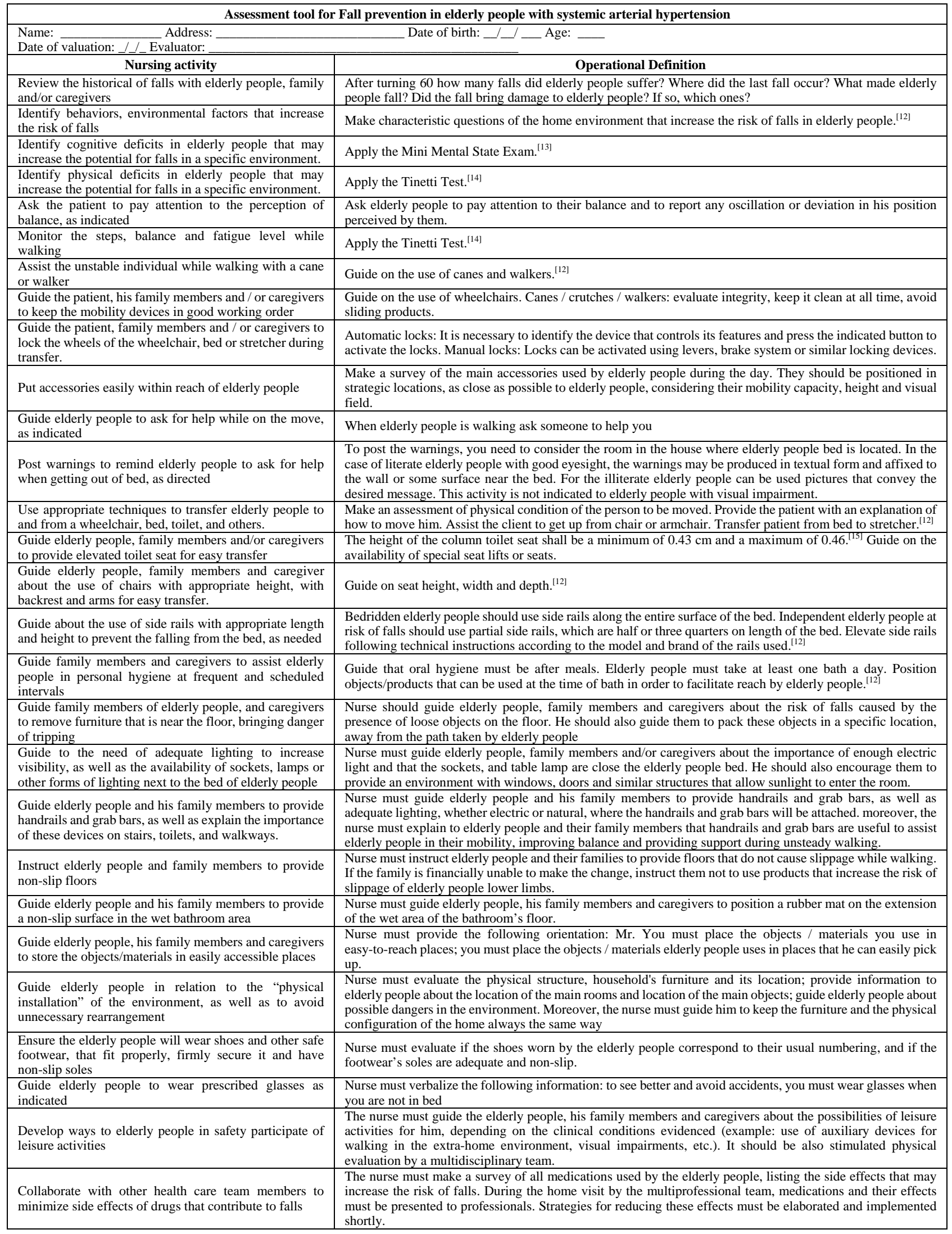


Nurse 03 performed the assessment tool application taking a time of, approximately, 26 minutes. It was observed he followed the sequence of the assessment tool activities. However, he made several adaptations to turn them into questions, that is, to make the activity of the intervention more operational and possible of being executed.

When comparing the reports of nurse 03 with the ones of nurses 01 and 02 , it was noticed differences in the assessment tool implementation mode. Overall, the nurse 03 assessment was superficial, based only on questions, without considering the physical and cognitive tests, which were performed by nurses 01 and 02 .
The application of the assessment tool by the nurse 04 took, approximately, 39 minutes. He judged that the assessment tool did not present sufficient clarity in its items, making it difficult to identify and encompass the proposal of each activity. Nevertheless, he considered the assessment tool appropriated for elderly people with arterial hypertension.

It was observed an application pattern similar to the one of nurse 03 on regarding of language adequacy and the superficiality in the intervention's implementation. A peculiarity of this professional was the difficulty with some terms present in the assessment tool, which according to him, could be replaced by simpler terms, such as, "floor" that refers to the ground floor.

Table 2. Evaluated items in the pretest stage of the assessment tool with nurses and elderly people with arterial hypertension and the nursing diagnosis Risk of falls, Redenção, Ceará, Brazil 2018.

\begin{tabular}{|l|l|l|l|l|}
\hline Evaluated items & Nurse 01 & Nurse $\mathbf{0 2}$ & Nurse 03 & Nurse 04 \\
\hline Assessment tool version & With the constitutive definitions and operational & Without the constitutive definitions and operational \\
\hline Application time & 56 minutes & 01 hour 21 minutes & 26 minutes & 39 minutes \\
\hline Adequation to public & Totally adequate & Needs adjustments & Totally adequate & Totally adequate \\
\hline Reviews & None & $\begin{array}{l}\text { Operational procedure } \\
\text { suggested }\end{array}$ & None & $\begin{array}{l}\text { Absence of clarification for } \\
\text { each activity }\end{array}$ \\
\hline
\end{tabular}

\section{Discussion}

Researches on Nursing Interventions Classification in primary health care are scarce. The literature evidences that, at this level of care, nurse have assumed, along the time, a managing role, which, added to high demand of users and services, makes difficult the utilization of nursing classification systems, including the NIC. ${ }^{[17]}$

It was observed that the validation process by specialists, through the focus group, was useful to make the nursing intervention assessment tool clearer and more objective. Furthermore, it was noticed that, because they were built to be used worldwide, the activities of nursing intervention Fall Prevention, in its original version, presented by NIC (2016), ${ }^{[9]}$ contained discrepancies in relation to reality of elderly people target of the study.

Research related to nursing taxonomies has recognized the effectiveness of the construction of constitutive and operational definitions for the practice of the nurse with the user, ${ }^{[18]} \mathrm{es}$ pecially when they are validated. The term validate can be defined as the degree to which a given construct is appropriate to measure the true value of what it proposes to measure, allowing to know how much the results obtained represent the truth and/or how far from it. ${ }^{[19]}$

At the national and international level, the use of validated assessment tools is increasing, which have a positive impact on the quality of care provided by nurses, since they facilitate the use of the nursing process and favor action based on science. ${ }^{[20]}$

In addition, the need to adapt activities to specific social and cultural contexts, it was verified the importance of standardizing the way how each intervention is implemented. Moreover, it highlights the relevance of having expert opinion in a joint meeting, focus group. Through it, it is possible to have discussion until reaching a consensus to indicate changes in the wording of the activities, making them more understandable to elderly people and nurse.

In view of this, a study to validate the content of a valuating assessment tool of care quality in an operating room showed that the utilization of focus group with experts was useful in evaluative research. This emphasizes the need to consider the view of different subjects on which incur the phenomenon to be evaluated, resulting in an enriching experience that gives security for continue on researching. ${ }^{[21]}$

Validation studies provide refinement and enhancement of classifications, stimulate critical thinking and reinforce nurses' decision making, as well as improve and standardize communication and nursing registration. The use of a standardized language promotes the universality of the utilization and dissemination of information. ${ }^{[22]}$

It is evident its usefulness in verifying if all items of the 
assessment tool are understandable to all members of the population for which it was intended. From the pretest evaluation it is possible to make changes at the assessment tool, making its items clearer. ${ }^{[23]}$

The pretest results showed that nurses who had access to assessment tools with operational definitions did not escape the method of implementing the nursing intervention, strictly following the suggested operational commands.

On the other hand, nurse 02 , even demonstrating some difficulties in applicate the assessment tool, was able to perform it satisfactorily, which is considered a positive finding to the study, since it is believed that even nurses who do not demonstrate familiarity with Nursing Interventions Classification (NIC) can effectively implement the assessment tool when this one has constitutive definitions and operational.

Nurses who had the assessment tool without definitions had an application time shorter than nurses who had the assessment tools containing the definitions. However, it was observed that they performed a superficial application, reduced only to questions and to answers provided by elderly people, without performing tests recommended in elderly people evaluation.

Therefore, it is believed that the existence of an assessment tool with the activities of nursing intervention fall Prevention may be effective to reduce the fall rates in hypertensive elderly people. Its use in primary health care is relevant and indispensable, since the main focus, in this service, is health promotion and harm prevention, fulfilling the purposes of nursing intervention fall Prevention.

It is noteworthy that, due to the insufficiency of scientific research with methodological design similar to that adopted by this study, it was not possible to compare the results obtained with those presented in other researches. This statement reiterates the importance of carrying out scientific studies with a focus on interventions in the Nursing Intervention Classification.

\section{Strengths and limitations}

A strong point of this study was the participation of at least one nurse in clinical practice in the process of evaluating and developing of the assessment tool. In research like this, it is difficult to gather a significant number of specialists, as most of them participate in other clinical, academic or scientific activities. The realization of the focus group was another strong point, since its realization contributed to a joint analysis of the assessment tool content and allowed the specialists to talk to each other until reaching a consensus.

A limitation of this research was the pre-test through a nurs- ing consultation at a health unit. It was most appropriate for the assessment tool to be tested through a home visit, since the nursing activities of the intervention to prevent falls in the elderly include actions focused on changing home risk factors, such as loose carpets and insufficient lighting.

The results of this study are not generalizable to different populations. It is noteworthy that the assessment tool includes only nursing activities for elderly Brazilians, especially those with high blood pressure and the Nursing Diagnosis falls Risk. In this sense, future research should adapt and validate the assessment tool for the prevention of falls in the elderly with other clinical conditions, in different geographical and cultural contexts.

\section{Conclusion}

In the study, it was developed an assessment tool to prevent falls in elderly people with arterial hypertension and nursing diagnosis Risk of falls. For this, it was used the NIC's intervention Fall Prevention. Despite of being used worldwide, this classification needs adaptations to be used in contexts and specific audiences. The final assessment tool contains 28 activities of intervention fall Prevention and its respective constitutive definitions and operational.

It was observed differences in the assessment tool application with and without constitutive definitions and operational.

The assessment tool that contained the constitutive and operational definitions took longer to be applied, but there was a similarity in the application of the assessment tool by nurses. This finding points to the importance of standardizing Nursing Interventions Classification through constitutive and operational definitions that guide nurses on how to apply these interventions in specific populations.

It is suggested that the assessment tool be tested and validated with elderly people in clinical context, cultural and social specific. Furthermore, this assessment tool may be used in other researches, clinical practice. Thus, this research brings unpublished contributions to elderly people health. One of them is the standardization of nursing intervention activities Prevention of falls in hypertensive elderly people.

It is noteworthy that chronic non-communicable diseases, such as hypertension, are one of the ten health priorities of the World Health Organization. Studies on this subject bring contributions to world health, with specific focus on the improvement of clinical practice in nursing. Among these contributions is the standardization of Nursing Interventions Classification for prevention of falls in elderly with clinical conditions and in specific cultural contexts. The constitutive and operational definitions will not only help nurses to ap- 
ply nursing activities, but also to standardize clinical care to reduce or control the risk factors for falls in elderly people with arterial hypertension and with the Nursing Diagnosis
Risk of falls.

\section{CONFLicts OF InTEREST Disclosure}

The authors declare that there is no conflict of interest.

\section{REFERENCES}

[1] Moraes SA, Soares WJS, Lustosa LP, et al. Characteristics of falls in elderly persons residing in the community: a population-based study. Rev. Bras. Geriatr. Gerontol [Internet]. 2017[cited 2020 Abr 05]; 20(5): 691-701. https://doi.org/10.1590/1981-22562 017020.170080

[2] American Geriatrics Society. Summary of the Updated American Geriatrics Society/British Geriatrics Society clinical practice guideline for prevention of falls in older persons. J Am Geriatr Soc [Internet]. 2010[cited $2020 \mathrm{Abr}$ 05]; 10(2): 1-15.

[3] Herdman TH, Kamitsuru S, organizadoras. Diagnósticos de Enfermagem da NANDA-I: definições e classificações: 2015-2017. ed. Porto Alegre: Artmed; 2018.

[4] Stevens JA, Rudds RA. Circumstances and Contributing Causes of Fall Deaths among Persons Aged 65 and Older: United States, 2010. J Am Geriatr Soc[Internet]. 2014[cited 2020 Abr 05]; 62: 470-5. PMid:24617970 https://doi.org/10.1111/jgs. 12702

[5] Callisaya ML, Sharman JE, Close J, et al, Greater daily defined dose of antihypertensive medication increases the risk of falls in older people - a population-based study. J Am Geriatr Soc[Internet]. 2014[cited 2020 Abr 05]; 62: 1527-1533. PMid:24934339 https : //doi.org/10.1111/jgs.12925

[6] Vitor AF, Lopes MVO, Araújo TL. Diagnóstico de enfermagem risco de quedas em pacientes com angina instável. Rev Rene [Internet] 2010 [cited 02 out 2019]; 11(1): 105-13.

[7] Silva JCA, Hazime FA, Campelo GO, et al. Capacidade de manutenção postural em diferentes atividades funcionais de idosos hipertensos e não hipertensos. Rev Bras Promoç Saúde [Internet] 2017 [cited 02 out 2019]; 30(1): 22-29. https://doi .org/10.5 $020 / 18061230.2017 \cdot \mathrm{p} 22$

[8] Lima DA, Cezario VOB. Quedas em idosos e comorbidades clínicas. Rev HUPE [Internet]. 2014 [cited 02 out 2019]; 13(2): 30-27. https://doi.org/10.12957/rhupe.2014.10130

[9] Bulechek GM, Butcher HK, Dochterman JM, et al. Classificação das Intervenções de Enfermagem (NIC). 6th ed. Rio de Janeiro: Elsevier; 2016.

[10] Organização Pan-Americana de Saúde. No dia internacional da pessoa idosa, a OPAS chama a atenção para o envelhecimento saudável [Internet]. [sem local]: OPAS. 2017 [cited 02 out 2019]. Available from: https://www.paho.org/bra/ind ex.pnh?option=com_content\&view=article\&id $=5515$ : no-dia-internacional-da-pessoa-idosa-opas-chama-a tencao-para-envelhcimento-saudavel\&ltemid $=820$

[11] Fehring R. The Fehring Model. In: Carrol-Johnson R, Paquete M, editores. Classification of nursing diagnoses: proceedings of the tenth conference of North American Nursing Diagnosis Association. Philadelphia: Lippincott; 1994.

[12] Pinheiro PCM. Validação de um instrumento para prevenção de quedas em idosos com hipertensão arterial [dissertação]. [Redenção (BR)]: Universidade da Integração Internacional da Lusofonia AfroBrasileira; 2018.

[13] Folstein M, Folstein S, McHugh P. "Mini-mental state". A practical method for grading the cognitive state of patients for the clinician. J Psychiatr Res[Internet].1975[cited 2020 Abr 05]; 12(3): 189-198.
Available from: https://www.sciencedirect.com/science/ article/abs/pii/0022395675900266?via\%3Dihub

[14] Tinetti ME, Baker DI, McAvay G, et al. A multifactorial intervention to reduce the risk of falling among elderly people living in the community. N Engl J Med[Internet]. 1994[cited 2020 Abr 05]1994; 331: 821-7. https://www.nejm.org/doi/10.1056/NEJM1 99409293311301?url_ver=Z39.88-2003\&rfr_id=ori: rid: crossref.org\&rfr_dat =cr_pub\%3dwww.ncbi.nlm.nih.gov PMid:8078528 https://doi.org/10.1056/NEJM199409293311301

[15] Associação Brasileira de Normas Técnicas. NBR 9050: Acessibilidade a edificações, mobiliário, espaços e equipamentos urbanos. Rio de Janeiro: ABNT, 2004.

[16] Alves VC, Freitas WCJ, Ramos JS, et al. Actions of the fall prevention protocol: mapping with the classification of nursing interventions. Rev. Latino-Am. Enfermagem[Internet]. 2017[cited 2020 Apr 05]; 25. Available from: http://www.scielo.br/scielo.php?script=sci_arttex t\&pid=S0104-11692017000100410\&lng=en

[17] Galavote HS, Zandonade E, Garcia ACP, et al. The nurse's work in primary health care. Esc Anna Nery Rev Enferm [Internet]. 2016 Mar [cited 2020 Apr 05]; 20(1): 90-98. Available from: http://www.scielo.br/scielo.php?script=sci_ar ttext\&pid=S1414-81452016000100090\&lng=en https://do i. org/10.5935/1414-8145.20160013

[18] Oliveira ARS, Araujo TL, Carvalho EC, et al. Construction and validation of indicators and respective definitions for the nursing outcome Swallowing Status. Rev. LatinoAm. Enfermagem [Internet]. 2015 Jun [cited 2020 Abr 05]; 23(3): 450-457. Available from: http://www.scielo.br/ scielo.php?script=sci_arttext\&pid=S0104-1169201 5000300450\&lng=pt\&nrm=iso\&tlng=en PMid:26155008 https://doi.org/10.1590/0104-1169.0377.2575

[19] Ribeiro MAS, Vedota TG, Lopes MHBM, et al. Estudos de validação na enfermagem: revisão integrativa. Rev Rene. 2013 [cited 2020 Abr 05]; 14(1): 01-14. Available from: http://www.periodicos.ufc .br/rene/article/view/3359

[20] LoBiondo-Wood G, Haber J. Pesquisa em enfermagem: métodos, avaliação crítica e utilização. $4^{\mathrm{a}}$ ed. Rio de Janeiro: GuanabaraKoogan; 2001.

[21] Gomes JA, Martins MM, Tronchin DMR, et al. Quality assistance processes in the operating room-validation of a scale. Journal Health Npeps[Internet]. 2018[cited 2020 Abr 05]; 3(2): 352-367. Available from: https://periodicos. unemat.br/index.php/jhn peps/article/view/3118 https://doi.org/10.30681/252 610103118

[22] Correia MDL, Duran ECM. Conceptual and operational definitions of the components of the nursing diagnosis Acute Pain (00132) Rev Latino-Am Enfermagem[Internet].2017[cited 2020 Apr 05]; 25. Available from: http://www.scielo.br/scielo.php?scr ipt=sci_arttext\&pid=S0104-11692017000100609\&lng=en PMid:29267544 https://doi.org/10.1590/1518-8345.2330.2973

[23] Coluci MZO, Alexandre NMC, Milani D. Construction of measurement instruments in the area of health. Ciênc Saúde coletiva[Internet]. 2015Mar[cited 2020 Apr05]; 20(3). Available from: http://www.scielo.br/scielo.php?script=sci_ar ttext\&pid=S1413-81232015000300925\&lng=en 